\section{ТЕРМІНИ ДЛЯ ХАРАКТЕРИСТИКИ ТУБУЛОІНТЕРСТИЦІЙНИХ ЗМІН}

Гострий тубулярний некроз - некроз епітелію канальців (зазвичай - коагуляційний).

Гострі тубулоінтерстиційні зміни включають набряк та інфільтрацію інтерстицію мононуклеарними клітинами (лімфоцити, макрофаги, плазматичні клітини), нерідко - 3 домішкою нейтрофілів і еозинофілів.

Tубуліт - інфільтрація епітелію канальців лімфоцитами, рідше - іншими клітинами запалення.

Тубулярна симпліфікація - дилатація проксимальних звивистих канальців, сплощення їх епітелію зі зменшенням або втратою PASпозитивної зони.

Тубулярна атрофія - сплощення епітелію та зменшення діаметру канальців зі стовщенням та зморщуванням тубулярної базальної мембрани. Асоціюється з фіброзом інтерстицію.

Хронічні тубулоінтерстиціальні зміни включають атрофію канальців, фіброз і запальну інфільтрацію інтерстицію.

\section{ТЕРМІНИ ДЛЯ ХАРАКТЕРИСТИКИ СУДИННИХ ЗМІН}

Артеріїт. Поліморфноядерний - сегментарна або циркулярна інфільтрація стінки артерії поліморфноядерними лейкоцитами $з$ домішкою мононуклеарних клітин. Інфільтрація лише адвентиції іменується периваскулярною інфільтрацією. Мононуклеарний - те саме, але переважно мононуклеарними клітинами. Гранулематозний - вогнищева інфільтрація стінки артерії великими мо- нонуклеарними клітинами, іноді - гігантськими.

Гіаліноз артеріол - акумуляція гомогенного еозинофільного та помірно PAS-позитивного матеріалу в стінці артеріол. Розпочинається процес в інтимі та поширюється на всю товщину стінки. Початкові зміни характеризуються наявністю дрібних гіалінових крапель. У складі гіаліну часто виявляються ліпіди та фібрин.

Мультиплікація внутрішньої еластичної мембрани артерій - багатошаровість внутрішньої еластичної мембрани.

Некротизуючий артеріоліт - фібриноїдний некроз стінки артеріол з інфільтрацією поліморфноядерними лейкоцитами та, рідше, мононуклеарними клітинами.

Стовщення інтими артерій - фіброзне стовщення інтимального шару, зазвичай з концентричним звуженням просвіту артерії.

Стовщення інтими артеріол - розширення в нормі дуже тонкого інтимального шару. Може бути наявною мукоїдна речовина.

Стовщення медії артеріол та артерій - стовщення середньої оболонки внаслідок гіперплазії та/або гіпертрофії гладком'язових клітин. В частині випадків у м'язових клітинах спостерігаються гідропічні зміни.

Фібриноїдний некроз стінки артеріол та дрібних apmepiŭ - нечітка структурна організація, каріопікноз та каріорексіс. Відсутня інфільтрація поліморфноядерними лейкоцитами. Виявляються ліпіди та фібрин. Може спостерігатись тромбоз судин та периваскулярні крововиливи.

(C) Фоміна С. П., Багдасарова I. В., Мигаль Л. Я., 2013

УДК 616.611-002-008.6-053.2

С. П. ФОМІНА, І. В. БАГДАСАРОВА, Л. Я. МИГАЛЬ

ПРОГНОЗУВАННЯ НЕСПРИЯТЛИВОГО ПЕРЕБІГУ ГЛОМЕУРЛОНЕФРИТУ 3 НЕФРОТИЧНИМ СИНДРОМОМ У ДІТЕЙ: ЕНЗИМУРИЧНІ МАРКЕРИ

FOMINA S. P., BAGDASAROVA I. V., MIGAL L. A.

\title{
PREDICTION OF UNFAVORABLE COURSE OF GLOMERULONEPHRITIS WITH NEPHROTIC SYNDROME IN CHILDREN: ENZYMURIC CRITERIA
}

\author{
Державна установа "Інститут нефрології НАМН України"
}

SI «Institute of Nephrology NAMS of Ukraine»

Ключові слова: нефротичний синдром, біологічні маркери, $N$-ацетил- $\beta$-Д-глюкозамінідаза,

Фоміна Світлана Петрівна

e-mail: sfomina@meta.ua $\beta$-галактозидаза, правдоподібності.

Key words: nephrotic syndrome, biomarkers, $N$-acethyl- $\beta$-D-glucosaminidase, $\quad \beta$-galactosidase, prognosis, likelihood ratio. 
Резюме. Цель исследования - изучение возможности использования определения активности реноспецифичных ферментов мочи у детей с гломерулонефритом, нефротическим синдромом (НС), в качестве биомаркеров прогнозирования неблагоприятного течения заболевания. Материалы и методы. У 209 детей, больных гломерулонефритом с НС, на разных этапах наблюдения в зависимости от течения заболевания рассчитаны операционные характеристики показателей, полученных при определении активности реноспецифичных ферментов - N-ацетил- $\beta$-Д-глюкозамінідази (НАГ) и $\beta$-галактозидаза ( $\beta$-Гал). Результаты. Повышение активности НАГи $\beta$-Гал мочи свидетельствует об активном включении в патологический процесс при НС тубулярного аппарата почек. Вероятность прогрессирования НС повышается при сохранении активности НАГ >50 ЕД и $\beta$-Гал >30 ЕД на 8-10неделе лечения и в катамнезе (через 1.5-3 года после отмены терапии), повышении уровня ферментов на 6-9 месяце поддерживающей терапии (НАГ >100 ЕД, $\beta$-Гал >60 ЕД). Изменение активности ферментов до начала терапии не несет прогностической нагрузки. На основании полученных данных создан энзимурический фрагмент системы мультимаркерного параллельного каскадного прогнозирования неблагоприятного течения заболевания. Заключение. Активность реноспецифических ферментов мочи (НАГ и $\beta$-Гал) целесообразно использовать в качестве маркеров прогрессирования ГН с НС у детей с учетом оптимальных сроков проведения исследований и диапазонов показателей, обобщенных в предложенной системе прогнозирования.

Summary. The aim of study was to investigate the possibility of using the detection of urine renospecific enzymes activity in children with nephrotic syndrome (NS) as biomarkers of unfavorable disease course prognosis. Materials and methods. The operating characteristics of urine activity values of $N$-acethyl- $\beta$-D-glucosaminidase (NAG) and $\beta$-galactosidase ( $\beta$-Gal) were estimated in 209 nephrotic children depending on disease course. Results. The high activity of $N A G$ and $\beta$-Gal confirms the active participation of renal tubules in pathological process in NS. Likelihood of NS progression increased while saving NAG activity $>50$ Units and $\beta-G a l>30$ Units in $8-10$ weeks of therapy and at 1.5-3 years of follow-up after treatment withdrawal; increasing of enzymes levels in 6-9 months on tapering treatment period ( $N A G>100$ Units, $\beta-G a l>60$ Units). Changing the enzymes $\mid$ activity in the disease active stage before treatment does not have the prognostic defense. The enzymuric fragment of multimarker parallel cascade system for prediction unfavorable NS course has been created. Conclusion. Urine renospecific enzymes activity (NAG and $\beta$-Gal) should be used as markers of the progression in NS children with the optimal terms studies and range parameters as summarized in the proposed prediction system.

ВСТУП. Особливе місце серед хвороб органів сечової системи займає гломерулонефрит 3 нефротичним синдромом (ГН з НС), який має неоднозначний прогноз і потребує тривалого імунотропного лікування. Прогнозування перебігу і наслідків ГН базується на значній кількості методик і тестів. Однак варіабельність клінічної ситуації та необхідності повторення досліджень в динаміці для встановлення вектору (напрямку) змін, який визначає прогноз, ускладнюють інтерпретацію результатів. Крім того, в клінічній практиці часто відбувається заміщення (ототожнення) прогностичних маркерів на маркери стану, які оцінюють важкість захворювання, але не мають прямого прогностичного навантаження. Наявність чи перевага у пацієнта тих чи інших ознак (проявів, патернів) віддзеркалює в цих випадках певний етап хвороби, але не можливий розвиток подій надалі. Прогностичні ж маркери дають змогу оцінити не тільки прогноз захворювання, а й відповідь на лікування, сприяють моніторингу ефективності терапії.

В рамках доказової медицини параметри, вибрані в якості оптимальних маркерів прогнозу, мусять мати підтверджений зв'язок з клінічними наслідками захворювання, тобто відповідати вимогам сурогатних (третинних) точок аналізу. Методики по їх визначенню повинні характеризуватися високою точністю, надійністю, відтворюваністю, мати відповідні операційні характеристики (специфічність та чутливість) [2]. Слід враховувати, що більшість процесів і механізмів іх розвитку в клінічній нефрології багатофакторні, встановити ступінь зв'язку і взагалі наявність відносин між якимись двома ознаками остаточно на сучасному етапі практично не можливо, але не висока специфічність методу (60-70\%) не зменшує ваги асоціації [9, 12]. Реальну цінність тесту в цьому випадку для конкретного хворого несе розрахунок ВП (відношення правдоподібності - likehood ratio ) [9, 10]. Залежно від поставленої мети цей показник свідчить про ризик наявності (відсутності) захворювання. В клінічній медицині є сенс використовувати не тільки загальні опції (хвора чи здорова людина), а й приватні випадки - можливість прогресування захворювання чи їі відсутність, вірогідність повної ремісії чи несприятливий перебіг хвороби. В такому разі при ВП позитивного результату $(\mathrm{BП+)} 2.00$ вірогідність (ризик) прогресування захворювання буде вдвічі вище у суб'єкта з наявністю ознаки, ніж без неї. Якщо ВП+ 1.00, то досліджуваний фактор не має прогностичної ваги. ВП негативного результату (ВП-) несе зворотне навантаження - відсутність ознаки збільшує ризик розвитку події. Найбільш корисними для клініциста є тести з ВП $\geq 5.00$, а ВП $\geq 10.00$ дає надію розглядати результат дослідження як безперечний закон.

Окрім уповільнення ШКФ (еталонного маркеру прогресування при будь-якій патології нирок), при ГН с НС визнана важливість дослі- 
дження таких параметрів як мікроальбумінурія, протеїнурія, рівень $\beta 2$-мікроглобуліну, реноспецифічних ферментів сечі, тощо [7, 8, 11]. Відомо, що при виникненні і прогресуванні патологічного процесу в нирках активність ферментів сечі посилюється за рахунок викиду із зруйнованих лізосом гідролітичних ензимів. Активність $\mathrm{N}$-ацетил- $\beta$-Д-глюкозамінідази (НАГ) та $\beta$-галактозидази ( $\beta$-Гал) розцінюють як інформативні та чутливі маркери стану тубулярного апарату, його проксимальних канальців [3, 7]. Дослідники розглядають зазначені ферменти і в якості маркерів прогнозу, однак без опрацювання їх зв'язку з вторинними (прогресування, ремісія) чи первинними (виживання) кінцевими точками аналізу з точки зору доказової медицини (з розрахунком операційних характеристик і ВП зокрема). Мета дослідження - вивчення можливості використання визначення активності реноспецифічних ферментів у дітей, хворих на ГН з НС, в якості маркерів прогнозування несприятливого перебігу захворювання.

ОБЕКТ ТА МЕТОДИ ДОСЛІДЖЕННЯ. Дизайн дослідження - одномоментне (crosssectional study), об'єкт - 209 дитини віком від 2 до 17-ти років, хворих на ГН з НС. Діагноз встановлено за наявності класичного симптомокомплексу захворювання (протеїнурія >3 г/доба або 1 г/ $\mathrm{M}^{2}$ для молодшої вікової групи, гіпоальбумінемія $<25$ г/л, гіперхолестеринемія > 6.5 ммоль/л, набряки). Пацієнти отримали комбіновану імунотропну терапію згідно протоколу - індукція ремісії за допомогою глюкокортикостероїдів та тривале (до 12 місяців) призначення імунодепресантів $[1,4]$. Стан хворих оцінено на різних етапах: в періоді розгорнутих клінічних проявів до призначення лікування (до лікування), в кінці застосування максимальних доз препаратів (8-10 тижнів), на підтримуючій терапії (6-9 місяців) та після завершення лікування через $1.5-3$ роки (катамнез). Залежно від наслідків захворювання (аналіз проведено через 3-5 років після завершення лікування) ретроспективно виділено групи зі сприятли- вим перебігом (ремісія) та прогресуванням (збереження активності НС без або з уповільненням швидкості клубочкової фільтраціі).

Комплекс обстеження, окрім загальноприйнятих методик, включав визначення активності НАГ і $\beta$-Гал за методом Покровського О. О. (1971), адаптованого нами для сечі [3]. Отримана в результаті дослідження величина ензимурії (в мкмолях пара-нітрофенолу, що утворився протягом 1 години) перераховувалася на 1 ммоль креатиніну сечі, що дозволило зменшити вплив діурезу на остаточний результат. Для полегшення сприйняття матеріалу надалі в роботі одиниці виміру активності реноспецифічних ензимів (мкмоль/год/ммоль креатиніну) представлено як ОД.

До контрольної групи (група порівняння) було включено 28 практично здорових дітей відповідного віку, без патології нирок із швидкістю клубочкової фільтрації за Шварцем $>90$ мл/хв./м².

Клініко-лабораторне обстеження хворих на етапах лікування та спостереження виконано у відділенні нефрології ДКЛ №7 м. Києва (клінічна база відділу дитячої нефрології ДУ «ІН НАМН»), ензимуричні дослідження - в лабораторії біохімії ДУ «ІН НАМН» (завідувач к. біол. н. Л. В. Король).

Матеріал опрацьовано 3 використанням методів варіаційної статистики (SigmaPlot 2000 for Windows Version 6.00, 1986-2000 SPSS Inc.). Дані для кількісних перемінних представлено як медіана/25;75 персентилі.

Для розрахунку операційних характеристик тестів на визначення активності ензимів у їх зв'язку з прогресуванням захворювання створено чотирипільні таблиці (“2х2”) для подальшого використання в он-лайн калькуляторі [10]. Особливістю формування таблиць стало уточнення станів (наявність чи відсутність захворювання) та результату тесту (позитивний чи негативний (табл.1).

Таблиия 1

Приклад побудови таблиці “2х2” для розрахунку операційних характеристик діагностичного тесту для прогнозування перебігу захворювання

\begin{tabular}{|l|c|c|}
\hline \multicolumn{1}{|c|}{ Пацієнти з } & Прогресуванням захворювання & Відсутністю прогресування (ремісією) \\
\hline Високим значенням & тест»+» & «тест»+» \\
досліджуваного показника & захворювання»+» & захворювання»-» \\
& А & Б \\
Низьким значенням & тест»-» & тест»-» \\
досліджуваного показника & захворювання»+» & захворювання»-» \\
& В & $\Gamma$ \\
\hline
\end{tabular}

При створенні таблиць ми прирівнювали “наявність захворювання" - його прогресуванню, “відсутність захворювання" - досягненню ремісії. "Тест позитивний” чи “тест негативний” залежало від розташування значення досліджу- ваної величини вище або нижче запропонованої межі. В представленій роботі для розрахунку вірогідності прогресування ГН з НС використано інтервали НАГ: > $17,>50,>100$ ОД; $\beta$-Гал: $>15$, $>30$ і $>60$ ОД. В кінцевому варіанті дослідження 
в якості найбільш актуальних характеристик досліджуваних тестів визнано ВП+.

РЕЗУЛЬТАТИ ТА ЇХ ОБГОВОРЕННЯ. АКтивність НАГ сечі у обстежених хворих з ГН, НС, становила 79.3/27.6;207.8 ОД (від 1.3 до 1494.3 ОД), що значно перевищувало показники, отримані в контрольній групі (10.2/8.8;13.3 ОД, $\mathrm{p}<0.001)$. Найвищих значень показник сягав в активній стадії захворювання до початку терапії (152.6/79.5;236.5 ОД). Протягом спостереження під впливом запровадженого лікування документовано реверсію активності ферменту (8-10 тиждень: 62.4/26.2;266.3 ОД; 6-9 місяців: $36.5 / 23.2 ; 101.3$ ОД), без відновлення до значень контролю в катамнезі (21.2/12.5;37.2 ОД).

Зростання активності $\beta$-Гал сечі у обстежених хворих, на відміну від НАГ, було менш вагомим 3 медіаною показника 31.4/13.4;72.2 ОД (від 0.9 до 468.8 ОД). Активність $\beta$-Гал в контрольній групи (умовно здорових) виявилася вірогідно нижче $(10.4 / 5.9 ; 13.2$ ОД, $\mathrm{p}<0.001)$. На етапах спостереження визначено поступове зменшення підвищених значень $\beta$-Гал з більш повним відновленням показника на етапі кінцевого аналізу (до лікування: 64.9/24.4;106.4 ОД; 8-10-й тиждень: 31.1/12.8;75.3 ОД; 6-9-й місяці: 28.4/12.8;60.8 ОД; катамнез: 19.5/9.8;33.6 ОД).

Встановлені зміни активності реноспецифічних ензимів свідчить про стан тубулярного апарату нирок в момент обстеження, тобто визначені показники є біомаркерами стану. Розрахунок операційних характеристик для застосованих діагностичних тестів з визначенням ВП+ та урахуванням інтервалів значень показників, етапу спостереження перевів застосовані тести в іншу площину, обгрунтовуючи їх використання в якості прогностичних біомаркерів.

При аналізі операційних характеристик тестів на етапі розгорнутих клінічних проявів до початку терапії жодного вагомого для прогнозу коефіцієнта ВП+ встановлено не було, що свідчило про відсутність прогностичного значення гіперензимурії як маркера прогресування ГН на цьому етапі (табл. 2 і 3).

\section{Визначення можливості прогресування ГН з НС у дітей при зростанні активності НАГ сечі на етапах обстеження}

\begin{tabular}{|c|c|c|c|}
\hline \multirow{2}{*}{ Показник } & \multicolumn{3}{|c|}{ Активність НАГ сечі } \\
\hline & $>17$ ОД & $>50$ ОД & $>100$ ОД \\
\hline \multicolumn{4}{|c|}{ до лікування } \\
\hline $\mathrm{B} \Pi+$ & $1.03(0.93-1.15)$ & $1.30(1.10-1.55)$ & $1.44(1.09-1.91)$ \\
\hline \multicolumn{4}{|c|}{ 8-10 тижнів } \\
\hline ВП+ & $1.18(1.04-1.34)$ & $2.43(1.75-3.36)$ & $2.94(1.87-4.60)$ \\
\hline \multicolumn{4}{|c|}{ 6-9 місяців } \\
\hline ВП+ & $1.18(1.02-1.37)$ & $1.93(1.17-3.20)$ & $3.52(1.85-6.67)$ \\
\hline \multicolumn{4}{|c|}{ катамнез } \\
\hline $\mathrm{B \Pi +}$ & $1.79(1.32-2.41)$ & $7.44(3.36-16.49)$ & $22.31(5.59-89.00)$ \\
\hline
\end{tabular}

Примітки: дані представлено як ризик (95\% довірчий інтервал); сірим кольором позначено зони високого ризику прогресування захворювання; ГН гломерулонефрит; НС нефротичний синдром; НАГ N-ацетил- $\beta$-Д-глюкозамінідаза; ОД одиниць (мкмоль/год/ммоль креатиніну); ВП+ відношення правдоподібності позитивного результату.

Таблиия 3

\section{Визначення можливості прогресування ГН з НС у дітей при зростанні активності $\beta$-Гал сечі на етапах обстеження}

\begin{tabular}{|c|c|c|c|}
\hline \multirow{2}{*}{ Показник } & \multicolumn{3}{|c|}{ Активність $\beta$-Гал сечі } \\
\hline & $>15$ ОД & $>30$ ОД & $>60$ ОД \\
\hline \multicolumn{4}{|c|}{ до лікування } \\
\hline $\mathrm{B} \Pi+$ & $1.10(0.93-1.29)$ & $1.29(1.00-1.67)$ & $1.40(0.96-2.03)$ \\
\hline \multicolumn{4}{|c|}{ 8-10 тижнів } \\
\hline $\mathrm{B} \Pi+$ & $1.39(1.07-1.79)$ & $2.29(1.59-3.29)$ & $3.53(1.90-6.57)$ \\
\hline \multicolumn{4}{|c|}{ 6-9 місяців } \\
\hline $\mathrm{B} \Pi+$ & $1.43(1.13-1.79)$ & $1.49(0.94-2.35)$ & $2.81(1.38-5.73)$ \\
\hline \multicolumn{4}{|c|}{ катамнез } \\
\hline BП+ & $1.72(1.18-2.50)$ & $3.48(1.80-6.72)$ & $6.38(1.55-26.27)$ \\
\hline
\end{tabular}

Примітки: дані представлено як ризик (95\% довірчий інтервал); сірим кольором позначено зони високого ризику прогресування захворювання; ГН гломерулонефрит; НС нефротичний синдром; $\beta$-Гал $\beta$-галактозидаза; ОД одиниць (мкмоль/год/ммоль креатиніну); ВП+ відношення правдоподібності позитивного результату. 
Ризик несприятливого перебігу захворювання на 8-10 тижні терапії зростав вдвічі при активності НАГ >50 ОД і $\beta$-Гал >30 ОД (ВП+ 2.43 та 2.29, відповідно). Досягнення більш високих значень НАГ (>100 ОД) прогноз суттєво не змінювали (ВП+ 2.94), але виявлення надвисоких величин $\beta$-Гал (>60 ОД) супроводжувалися зростанням вірогідності прогресування (ВП+ 3.53).

На підтримуючій терапії (6-9 місяць) ризик прогресування зафіксовано при підвищені межі показників та зменшенні інтервалів активності ферментів (НАГ > 100 ОД, $\beta$-Гал >60 ОД, ВП+ 3.52 та 2.81, відповідно). Рівень ензимурії нижче зазначених меж, хоча і міг перевищувати втричі норму (показники контрольної групи), не був свідчення подальшого несприятливого перебігу захворювання, залишаючи хворим шанс на відновлення канальцевого апарату.

В катамнезі прогресування ГН з НС можна було прогнозувати вже при незначному підвищенні НАГ > 17 ОД (ВП+ 1.79), при рівні показника $>50$ ОД вірогідність зростала в 7 і більше разів (ВП+ 7.44), а >100 ОД - в 22 рази (ВП+ 22.31). Високі значення ВП+ були характерні і при дослідженні $\beta$-Гал сечі: в інтервалі $>15$ ОД (ВП+ 1.72), значно зростаючи при звуженні діапазону (>30 ОД: ВП+ 3.48; >60 ОД: ВП+ 6.38).

Отримані результати дозволили створити ензимуричний фрагмент, який доповнив розроблену нами раніше систему мультимаркерного каскадного прогнозування (рис. 1) [4-6].

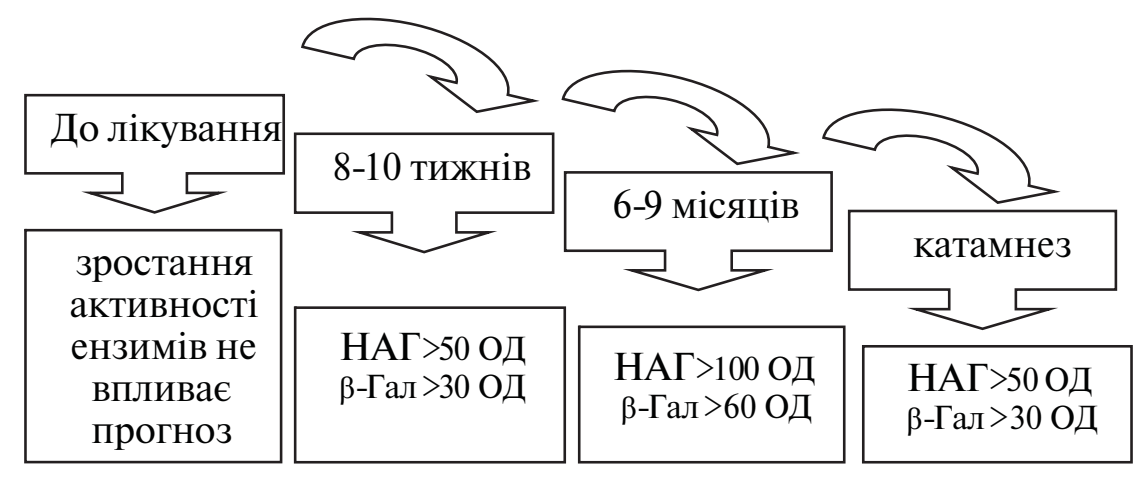

Примітки: НАГ N-ацетил- $\beta$-Д-глюкозамінідаза; $\beta$-Гал $\beta$-галактозидаза; ГН гломерулонефрит; НС нефротичний синдром; ОД одиниць (мкмоль/год/ммоль креатиніну).

Рис. 1 Внесок ензимуричних маркерів сечі НАГ і $\beta$-Гал в систему каскадного паралельного мультимаркерного прогнозування несприятливого перебігу ГН з НС у дітей на різних етапах спостереження.

В основу системи закладено новий методологічний підхід до опрацювання традиційних діагностичних методик, який відповідає принципам доказової медицини - визначення межевих значення показників та розрахунок операційних характеристик для кожного інтервалу (діапазону) значень. Це дає змогу виділити оптимальні строки проведення досліджень, за яких отримані межеві значення набувають прогностичної цінності щодо прогресуючого перебігу ГН. В цьому випадку інтервальні значення результатів тесту набувають ваги сурогатних або третинних кінцевих точок наслідку (біомаркерів), співвіднесених з прогресуванням - наслідком захворювання у вигляді несурогатної вторинної кінцевої точки. Формування прогностичної системи 3 такого комплексу кінцевих точок (сурогатних та несурогатних) наближає результати дослідження до цілісної та якісної оцінки ефективності терапевтичного втручання. Зазначена система передбачає проведення паралельних досліджень 3 визначенням декількох показників (від найбільш чутливих до найбільш специфічних), що підвищує їх прогностичну цінність без зниження точності чи зростання вартості. Мультимаркерність системи дає змогу вибрати доступний для клініки тест, у випадку необхідності - відмовитися від серійних (повторних) досліджень у конкретного хворого. Використання при створенні такої системи принципу каскаду (принципу доцільності проведення тесту на конкретному етапі спостереження послідовно від початку терапії до катамнезу) полегшує іiі застосування в клінічній нефрології. Актуальним є відкритість системи для поповнення іншими тестами, не використаними в даному дослідженні, як загально відомими, так і новітніми, значимість яких для прогнозу перебігу опрацьовано з залученням актуальних і простих операційних характеристик (ВП+, ВП-)

ЗАКЛЮЧЕННЯ. Для виваженої оцінки терапевтичного втручання доцільно формувати систему несурогатних і сурогатних наслідків захворювання, які визначають якісне виживання пацієнта на індивідуальному рівні. Дослідження активності ферментів сечі з лізосомною локалізацією та найбільш органоспецифічними властивостями щодо нирок показано використовувати в якості маркерів прогресування ГН з НС у дітей, враховуючи оптимальні терміни проведення тестів та межеві інтервали показників, узагальнених в запропонованій системі прогно- 
зування. Визначення цих маркерів при застосуванні сучасних методів аналізу даних збільшує цінність обсерваційних досліджень і в змозі дати відповіді на питання, які не можна вирішити через клінічні випробування або експеримент.

\section{ЛІТЕРАТУРА:}

1. Багдасарова И. В. Иммуносупрессивная терапия нефротического синдрома у детей / И. В. Багдасарова, С. П. Фомина // Український журнал нефрології та діалізу. - 2007. - № 4. - С. 31-36.

2. Березин A. E. Клиническое и прогностическое значение биологических маркеров в стратификации пациентов с кардиоваскулярными заболеваниями (обзор литературы) / А. Е. Березин // Укр. мед. часопис. - 2010. - № 6 (80). С. 79-85.

3. Лісозомна ензимурія як критерій дисфункції проксимальних канальців нирок у дітей при прогресуванні гломерулонефриту / Л. Я. Мигаль, I. В. Багдасарова, I. Є. Сербіна, Т. В. Кіндій // Перинатологія та педіатрія. - 2003. - № 3. C. 39-41.

4. Фоміна С. П. Імунотропна терапія дітей, хворих на гломерулонефрит 3 нефротичним синдромом: автор. ... доктора мед. наук : 14.01.37 / С. П. Фоміна. K., 2013. - 36 c.

5. Фоміна С. П. Маркери прогресування нефротичного синдрому у дітей / С. П. Фоміна // Педіатрія, акушерство та гінекологія. - 2012. - № 6. C. 22-25.

6. Фомина С. П. Радионуклидные маркеры прогрессирования гломерулонефрита с нефроти- ческим синдромом у детей / С. П. Фомина // Международный журнал педиатрии, акушерства и гинекологии. - 2012. - № 3. - С. 12-16.

7. Bazzi C. Urinary $\mathrm{N}$-acetyl-b-glucosaminidase excretion is a marker of tubular cell dysfunction and a predictor of outcome in primary glomerulonephritis / C. Bazzi, C. Petrini, V. Rizza, [et al.] // Nephrol. Dial. Transplant. - 2002. - Vol. 17. - P. 1890-1896.

8. Beta-2-microglobulin is superior to N-acetyl-betaglucosaminidase in predicting prognosis in idiopathic membranous nephropathy / Hofstra J. M., Deegens J. K. J., Willems H. L., Wetzels J. F. M. // Nephrol. Dial. Transplant. - 2008. - Vol. 23. - P. 2546-2551.

9. Biomarkers definitions working group. Biomarkers and surrogate endpoints: preffered definitions and conceptual framework // Clin. Pharmacol. Ther. 2001. - Vol. 69 (3). - P. 89-95.

10. KT Clearinghouse [Електронний pecypc] / Canadian institute of health research, Centre for evidence-based medicine. Toronto, 2000-2011. - Режим доступу : http://ktclearinghouse.ca/cebm/ practise/ca/

11. Lemley $K . \quad V$. An introduction to biomarkers: applications to chronic kidney disease / K. V. Lemley // Pediatr. Nephrol. - 2007. - Vol. 22. - P. 18491859.

12. Tesch G. H. Review: serum and urine biomarkers of kidney disease: a pathophysiological perspective / G. H. Tesch // Nephrology. - 2010. - Vol. 15. P. 609-616.

Надійшла до редакції 29.07.2013 Прийнята до друку 07.08.2013

(c) Топчій І.І., Семенових П.С., Гальчінська В.Ю., Якименко Ю.С., 2013

УДК:616.6:616.379-008.64-085

\title{
І.І. ТОПЧІЙ, П.С. СЕМЕНОВИХ, В.Ю. ГАЛЬЧІНСЬКА, Ю.С. ЯКИМЕНКО ОСОБЛИВОСТІ НЕФРОПРОТЕКТОРНОЇ ДІЇ СУЛОДЕКСИДУ У ХВОРИХ НА ДІАБЕТИЧНУ НЕФРОПАТІЮ
}

\section{I.I.TOPCHIY, P.S. SEMENOVYKH, V.YU. GALCHINSKAYA, YU.S. YAKIMENKO \\ PECULIARITIES OF NEPHROPROTECTIVE EFFECT OF SULODEXIDE IN PATIENTS WITH DIABETIC NEPHROPATHY}

\author{
ДУ «Національний інститут терапії ім. Л.Т.Малої НАМН України», м. Харків \\ SI «National Institute of Therapy named after L. Malaya of NAMS of Ukraine», Kharkov
}

Ключові слова: діабетична нефропатія, моноцитарний хемоатрактантний протеїн 1 типу, інгібітор активатора плазміногена 1 типу, запалення, фіброз, сулодексид, мікроальбумінурія.

Key words: diabetic nephropathy, monocyte chemoattractant protein type 1, plasminogen activator inhibitor type 1, inflammation, fibrosis, sulodexide, microalbuminuria.

Резюме. Введение. Моноцитарный хемоатрактантный протеин 1 типа (МСР-1) и ингибитор активатора плазминогена 1 типа (PАI-1) играют ключевую роль в реакциях воспаления, фиброза $и$ прогрессирования ренальной дисфункции. Преимущества сулодексида в лечении сосудистой патологии доказаны в клинических испытаниях, однако, его эффективность при диабетической нефропатии

Топчій Іван Іванович (ДН) исследована недостаточно

itopchiy@yandex.ua

Цель работы - изучение влияния сулодексида на динамику клинико-лабораторных показателей и уровни МСР-1 и РАI-1 в плазме крови больных ДН. 